\title{
Cohen, D.: Three Lectures on Post-Industrial Society
}

\section{Book review by Guy Standing}

This version was accepted for publication in the Journal of Economics, Vol.98, No.3, 2009, pp.261-266. The published article is available at http://econpapers.repec.org/article/kapjeczfn/v_3a98_3ay_3a2009_3ai_3a3_3ap_3a261-266.htm

This is an elegant little book, of less than 100 pages, that is in the French tradition of an essay. Just as with Montaigne's essays, one may read it for flashes of insight and anecdotal imagery, rather than as a scientific treatise or prescription for a political strategy. It largely avoids critical engagement. This and the essay form are its strength and its weakness. It may satisfy those with a general knowledge of public affairs. It is surely frustrating for any reader familiar with the relevant research and literature. Scholars should also be warned that what might sound nice as a lecture rarely turns nicely into a book. Compressing a lot into a little is a fine art. Few can do it well, and all should think long and hard before trying.

Problems start with the concept of 'post-industrial society', since it suggests the person cannot characterise today, other than by saying it comes after something. To make it more confusing, Cohen claims there was one industrial society model whereas there are several post-industrial societies (p. 9, for example). There is no consistent periodisation. On page 2 we are told "the industrial society of the 20th century linked a mode of production to a mode of protection". Note the singular in each case. Later, in chapter 3, he uncritically endorses Gosta Esping-Andersen's view that in the $20^{\text {th }}$ century there were three models of social protection, or welfare state.

Some commentators, including this reviewer, see globalisation as generating pressures towards convergence of national structures and policies. Cohen seems to be a 'divergenist' (to coin a term). Thus he claims that, with globalisation (which he calls the second globalisation, creating problems that we address later), "various social models seem to be drifting apart" (p. 9). There is little in the book to show that this is the case.

This is a problem with a grand essay (albeit in the form of 'three lectures'), for in trying to cover a vast terrain inevitably the essayist must make sweeping generalizations that leave him open to attack, and which cannot be substantiated in the essay format. But what a reader can be justified in wanting is a clear, convincing narrative. Here Daniel Cohen may come to feel that he has failed to provide it, even though one senses he could have done so had he been pressed to do so.

Chapter 1 begins by making a fleeting reference to Karl Polanyi's 'Great Transformation', which Cohen says "occurred in the 19th century" (p. 11). The text does not elaborate. This is surely to misrepresent Polanyi. The gist of his analysis was that in the 19th century financial capital became dominant in pushing for a market society in a period when the economy was 'disembedded' from society, implying that there were no appropriate mechanisms of regulation, redistribution and social protection that would have checked the relentless growth of economic insecurity and inequality.

\footnotetext{
${ }^{1}$ For a set of assessments of Polanyi's work, see A. Bugra and K. Agartan (eds.) Reading Karl Polanyi for the Twenty-First Century: Market Economy as a Political Project (Basingstoke, Palgrave Macmillan 2007).
} 
Eventually, crises occurred in the early 20th century, leading to political populism and extremism and a set of horrors, after which the state moved to re-embed the economy in society, ushering in variants of the welfare state. In other words, the Great Transformation did not occur in the 19th century. The claim that it did is reiterated at the end of the book, where he says "the economy freed itself from the tutorship of the state and claimed autonomy" (p. 91). A more correct way of putting it would have been that the interests of financial capital captured the state, inducing governments to make reforms in their interest. The autonomy that finance sought was really power, so that the policies and institutions built up intensified their wealth and control. The word autonomy gives an impression that the financiers were outside the state and not dependent on it for their opulence and activities.

Cohen's starting premise permeates the book. He later presents what he calls the second globalisation as a Transformation, rather than a phase of disembeddness that would precipitate a crisis. It is thus unsurprising that he does not identify a looming crisis, let alone warn of a global financial crisis. The timing of his book was unfortunate. But his way of depicting globalisation and post-industrial society provides no means of foreseeing such a crisis.

He does paint a sketch of what he calls 'five ruptures' - a new industrial revolution, a social rupture associated with "a new way of conceiving human labour", a cultural revolution based on 'individualism', financial market ascendancy that, according to Cohen, is unrelated to the other ruptures, and the entry of China and India into world capitalism, which "owes little to the other ruptures" (p. 12). This way of looking at trends lacks a coherence of a model of transformation. Without that, one is left with a series of disjointed anecdotes.

Perhaps most crucially, Cohen steers clear of class and the struggles that take place between interests in society. But financial markets did not become ascendant by chance or as a result of intervention from some deus ex machina, nor did those other ruptures materialise autonomously. But there is no sense of agency in the essay. He could have gained by dabbling in some dirty water.

While steering clear of class, Cohen tells us that there has been a "flattening of the hierarchical structure" in the organisation of work (p. 16). Here he touches on something that has preoccupied this reviewer in a trilogy of books. Suffice it to say there is little evidence of flattening. The examples Cohen cites scarcely help his cause. He claims managers are now more 'productive' because they have taken over 'the labour of typists'. One could just as easily argue that managers obliged to spend a lot of time word processing are spending less time doing tasks by which they could provide high value added. The reality, probably, is that more managers are overstretched, losing control of their labour and time in general. But there is a disconnect in the book, for at some places we are told there used to be a cosy relationship between managers and workers that has broken down, while at others we are told a strong hierarchy has diminished.

Again, the trouble is that painting a sketch of a vast terrain requires generalisations, which are overstretched. The claim (p. 18) that "skilled work became more productive, so its remuneration could rise" is typical. Besides the difficulty of defining 'skilled' in historical terms, there is the 
little matter of bargaining power. Assembly workers in the car industry long earned much more than nurses, on average. It is not clear that the former are more 'skilled' than the latter.

Having claimed there is a flattening of the hierarchical structure, Cohen asserts that "there is now a greater probability of remaining at the bottom of the wage structure for life" (p. 19). Whatever hierarchy means, surely a feature of a flatter structure would be the opposite of this. Moreover, there is overwhelming evidence that wage and earnings differentials have vastly increased, again scarcely consistent with a flatter structure. There is a missing element in his perspective. Wider earnings differentials and stagnating median wages are partly a reflection of the systematic political curbing of collective bargaining combined with the effects of globalisation, on which Cohen is trapped by his narrow view of what it constitutes, as we will see.

Before coming to that, it is worth reflecting on Cohen's section on "May 1968". He was a little young at the time. I was an insignificant foot soldier. But to claim that the 1968 revolts were severest in Germany, Italy and Japan, because those countries were the perpetrators of the Second World War, is absurd (p. 27). I recall events in France, UK, USA and Greece. Remember Paris, London, Berkeley?

Cohen sees May 1968 as "the emergence of youth as an autonomous social force". I have long argued against economists who saw the preceding era as "the golden age of capitalism", and agree with Cohen that 1968 did "fracture the standardised world created by their parents", although think it a bit unfair to attribute that world to those who were the victims or bystanders of its creation. The trouble is that the image is limited, merely stating the obvious, that the revolts were mostly led by youth. Most upheavals in history have been dominated by the young, although in 1968 there were plenty of older workers who joined strikes, and leading figures were ageing academics, such as Herbert Marcuse.

A better image could have been drawn from a proper reading of Polanyi. The events of 1968 marked thewaning period of social democracy, in which an embourgeoisement of what had been known as the working class had taken place. Polanyi's Transformation had run its course; henceforth the model built up by his generation went into retreat, hesitantly at first, but after the collapse of Keynesianism in the mid-1970s, at full throttle in the 1980s as the political right gained ascendancy. Social democrats of various kinds tried to hold political office, but increasingly either failed or did so only by making messy compromises with economic liberalism.

There is nothing on this in Cohen's essays. I do not see how one can tell a coherent story of 'post-industrial society' unless one deals with the political economy of the time. It is a shame, for the story reached its nadir in the financial market crisis of 2008-2009, in which social democracy was swept away across Europe, culminating in virtual disappearance in Italy, defeat in Germany in September 2009 and an impending meltdown in the UK in 2010. The fact is that social democrats had presided uncritically over growing economic insecurity and inequality, allowing a more hierarchical society to confront the new youth, who were tripping unsteadily into the emerging precariat. 
Cohen's second essay hinges on a claim that the era before the Great War was "the first globalisation". The parallels drawn between then and the post-1980 "second globalisation" are unconvincing. He begins by claiming that Russia, India and China all 'participated' in the first globalisation, implying that this was no different from nowadays. This is fanciful, since one country was still quasi-feudal, one a fragmented colony of the British Empire and one subject to warlords and mercantile foreign domination and exploitation. Trade essentially involved the rich industrialised countries exporting manufactured goods, while they imported raw materials and primary goods from the underdeveloped countries. This is dramatically different from the globalization era. In the 19th century, trade took place largely in complementary goods and services, not competitive ones.

A problem with equating the pre-1914 and post-1980 eras is that it turns attention away from the uniqueness of the latter period. When Keynes sat in his study and marvelled at how he could obtain tea from Ceylon and spices from the Orient, he was looking at a world that in his view was producing complementary goods. Today, globalisation is about an open market system in which competitive pressures are dominant. If workers demand something in one country, employers and financial capital can merely switch production and investment to a lower-income place where workers are cowed.

The failure to see the uniqueness of globalisation is revealed in various ways. Cohen says the "present globalisation lags behind its predecessor in at least two essential dimensions: financial globalisation and international migration" (p. 38) Saying that Britain exported more of its savings before 1913 than it does now does not imply that the two periods are similar. Today, savings and capital flow in all directions. It is the large developing countries that have been exporting their savings to prop up living standards and allow huge deficits in the USA and several other rich countries. As for the comment on migration, whereas at the outset of the $20^{\text {th }}$ century most consisted of Europeans moving to settle in the New World, forging an industrial working class in the USA, much of today's migration is from low income countries to provide cheap labour in rich countries and in certain regions of developing countries. The mobility is between all parts of the world, much of it circulatory, much of it illegal or undocumented. It also results in a huge informal flow of 'capital', in the form of remittances, much of that being undocumented as well.

From his view of the 'first globalisation', Cohen concludes that all countries that would become the Third World learned that "world trade is not a source of enrichment for poor nations" (p. 40). On the contrary, many realised they could only benefit by becoming exporters of manufactured goods. This led to the rise of Japan and the NICs, which leveraged the international redivision of labour that has epitomised the one-and-only globalisation era. China and India were to be the primary beneficiaries as they rushed to embrace export-led economic growth.

Again, Cohen's two-globalisation pose lets him down. There is a peculiar section postulating a 'centre-periphery' system, in which "the centre is rich.... because it fosters specialisation on the part of its members" (p. 46). Then he claims, "In the new international division of labour, the rich tend to sell immaterial goods and buy material goods." This is too dualistic. It may sound good in a lecture, but it does not travel well into a book. Many of today's poorest produce or live off immaterial goods (services). 
They belong to the swelling global precariat, many doing menial insecure jobs in the global economy. The really rich mostly live off capital and rent, many not selling anything at all. Some are executives, managers, shareholders and members of the salariat attached to global MNEs, which may well sell material goods even if those doing the labour are scattered across the globe.

This prompts a crucial point that Cohen does not mention. Globalisation has created a globalising open labour market, in which the entry of 'Chindia' has meant, roughly, a quadrupling of the labour supply to the open market system, which has profoundly weakened the bargaining position of almost all those who live predominantly by supplying labour. Anything that takes a physical form can be produced almost anywhere, and the wages of Chinese workers are still less than a tenth of those of German or American workers, while their productivity is certainly much more than a tenth of theirs.

Cohen's second lecture concludes with a few demographics that he sees as linked to globalisation. There is one interesting statement (p. 55): "Today the world holds 6 billion human inhabitants: 1 billion rich ones, 1 billion who aspire to become rich, and 3 billion poor ones." One wonders what happened to the disappearing billion. But on what grounds can Daniel Cohen or any of us say there are a billion "rich" and a billion who aspire to be so? Do none of the 3 or 4 billion others not aspire to be rich?

Finally, chapter 3 deals with the European social model, a term that raises the hairs on the arms of this reviewer. Cohen claims (p. 60) that in the past 20 years there has been "increasing differentiation between social models in the EU". No evidence is given. He begins by referring to old differentials, first reiterating Philippe d'Iribarne's three modes of liberty, which he claims are British (Lockean), German (Kantian) and French. He then cites, wholly approvingly, EspingAndersen's 1990 model of three welfare state regimes (liberal, corporatist and social democratic). In other words, he believes Europe was differentiated. What is unclear is how those models - if one accepts them - have become more differentiated. This reviewer believes there has been a convergence, and that none of the terms used by Esping-Andersen captures the sense in which social and labour market policy has become directive. ${ }^{2}$

In one of the few places where Cohen uses statistics, the text diverges from the data. He says (p. 67) that countries where unemployment was lowest in the 1960s are those where it is highest today. His Table shows otherwise. For instance, Denmark had one of the lowest rates in the 1960s and in 2006, the final date given; Switzerland had the lowest rate in the 1960s and in 2006. He compounds his problem by pronouncing magisterially, "European unemployment no longer has any meaning" (p. 67), saying that a gap had opened up between the high unemployment countries of France, Germany and Italy and the rest. His own Table does not support this, and nor do other data he could have cited.

Although there is surely some path dependency, and although some European countries have managed to disguise some of their unemployment, notably by using incapacity benefits and labour subsidies to prop up jobs, this reviewer believes that convergence is the dominant trend

\footnotetext{
${ }^{2}$ For an elaboration of this, and for an analysis that underpins this critique, see G. Standing, Work after Globalisation: Building Occupational Citizenship (Cheltenham, Edward Elgar 2009).
} 
across European labour markets, with country after country adhering to the dictates of labour market flexibility, curbing corporatist arrangements, dismantling employment security regulations and enforcing more directive regulation (not deregulating), while moving steadily towards workfare 'active' labour market policies combined with means-testing social assistance. Everywhere, it is accentuating the extent of economic insecurity and anxiety. It is a phase that is unsustainable, as Polanyi would have understood.

Daniel Cohen is a distinguished French economist who deserves to be taken seriously. This review has tried to give his book the respect his status merits. He has raised many provocative issues. Perhaps they are just too complex to make an essay. 